\title{
Effect of Preparation Treatments on the Physico-Chemical Characteristics of Nile Tilapia (Oreochromis niloticus) Protein Concentrate
}

Istyqamah Muslimin $^{1}$, Syahrul$^{2}$, Metusalach $^{2}$

${ }^{1}$ Fisheries Science Study Program, Faculty of Marine and Fisheries Sciences, University of Hasanuddin, Makassar, Indonesia ${ }^{2}$ Department of Fisheries, Faculty of Marine and Fisheries Sciences, University of Hasanuddin, Makassar, Indonesia Corresponding author: mminanga@ hotmail.com

Received: 19 Nov 2021; Received in revised form: 04 Jan 2022; Accepted: 16 Jan 2022; Available online: 23 Jan 2022 C2022 The Author(s). Published by Infogain Publication. This is an open access article under the CC BY license (https://creativecommons.org/licenses/by/4.0/).

\begin{abstract}
Fish protein concentrate (FPC) is a concentrated protein derived from fish meat and its characteristics are highly dependent on the methods of preparation used. The purpose of this study was to determine the effect of different preparation treatments on the physico-chemical properties of niletilapia (Oreochromisniloticus) fish protein concentrate.The nile tilapia used. Was collected alive from shrimp ponds in Pangkep Regency, South Sulawesi, Indonesia. The fish was then filleted, red meat trimmed and white meat was chopped in a commercial food processor and stored in a zipped plastic bags at $-20^{\circ} \mathrm{C}$ until used. The meat was divided into two groups for treatments of pressing and unpressing. The pressed and unpressed chopped meat was then washed with $90 \%$ ethanol $(1: 2$ or 1:4, w/v) for 20,40 and 60 min. to remove lipid and pigments. The treated meat was then dried overnight in a forced-air convection oven. The dried nile tilapia FPC was then analysed for its physico-chemical characteristics. The results indicated that the preparation treatments significantly affected the characteristics of the nile tilapia FPC. The best results from each treatment showed characteristics according to FAO standards (1976) namely the ratio of washing ratio 2:1 with an extraction time of 60 minutes and the variation of the sample before extraction was pressed having a chemical composition of $85.32 \%$ protein, $0.55 \%$ fat, water content of $11.91 \%$ and ash content of $1.25 \%$. And the physical characteristics include $85.9 \%$ whiteness, $2.43 \mathrm{~g} / \mathrm{ml}$ water absorption and $2.37 \mathrm{~g} / \mathrm{ml}$ oil absorption. The results of this study indicated that the tilapia fish FPC is classified as type A FPC and is well applied to food ingredients.
\end{abstract}

Keywords-Ethanol, fish protein,pressing, washing, water absorption, whiteness.

\section{INTRODUCTION}

Tilapia (Oreochromis niloticus) is considered as a pest in shrimp and milkfish ponds in Indonesia and is often not utilized. In fact, this species of fish has good potential to be utilized for direct fresh consumption and converted into different processed products which will give additional income especially to fish farmers. Utilization of tilapia as a source of animal protein is one alternative in order to provide a nutrient-rich food source due to its high protein content. Protein is very important for cell structure, the function of antibodies to fight infection, regulation of enzymes and hormones, growth and repair of body tissues. Protein is also a major product in the food industry, and can also be provided in the form of protein concentrates. One of the opportunities that can be developed is to develop good nutritional products through fortification with fish protein concentrates [1].

Fish protein concentrate (FPC) is a fish flour product produced by reducing fat and water, resulting in a high protein content and easy to apply to low protein foods [9]. [6] Classified FPC into three types, namely Type A, which is tasteless, colorless and odorless, with a minimum protein content of $67.7 \%$ and a maximum fat content of $0.75 \%$. Type B has a fat content of less than $3 \%$ and the fish flavor is still noticeable in most of the foods to which it is added. FPC Type C, is fish flour which is produced hygienically, 
with a fat content greater than $3 \%$, as well as a strong fish odor and flavor.

In producing FPC, many researchers use organic solvents such as ethanol to extract the fat. [15] used ethanol to extract fat from skipjack roe and produced FPC with protein and fat contents of $70.01 \%$ and $6.09 \%$, respectively. [16] produced FPC from rainbow runner fish using $90 \%$ ethanol and obtained the protein and fat of $85.34 \%$ and $3.28 \%$, respectively, while [17] obtained the protein and fat of $77.34 \%$ and $1.22 \%$, respectively, for the same species of fish. [20] using 95\% ethanol to produce FPC from tuna and red with the protein and fat of $79.90 \%$ and $2.83 \%$, and $80.72 \%$ and $3.75 \%$, respectively.

Generally all fish can be used as raw materials for making FPC, but non-economical or low economic value fish are the main choice to be use properly, and even dumping the fish which causes pollution around the fish farming ponds. Therefore, this study produced the FPC from tiliapia and characterizedits physico-chemical properties in search of a better utilization of the tilapiafish.

\section{RESEARCH METHOD}

\subsection{Research Object and Location}

The object of this research is fish protein concentrate from tilapia fish which is barely utilized by the shrimp and milkfish pond farmers. The research was carried out from September 2020 to January 2021. The FPC production was carried out at the Fishery Product Technology Laboratory of the Faculty of Marine and Fisheries Sciences, Hasanuddin University. Chemical analysis was carried out at the Biochemistry Laboratory of the Department of Product Processing Technology, Pangkep State Agricultural Polytechnic. The physical properties analysis of the FPC was carried out at the PKP Integrated Laboratory, Hasanuddin University.

\subsection{Research Design and Methods}

The experiment was carried out using a completely randomized factorial design (CRFD) with 3 factors, namely: (1) extraction ratio $(2: 1$ and $4: 1 \mathrm{w} / \mathrm{v})$; (2)extraction time (20, 40 and $60 \mathrm{~min})$; (3) pressing (unpressed and pressed). Each treatment was repeated 3 times.

\section{a. Research procedure \\ - Sample preparation}

Tilapia fish was filleted and skinned, and the skinless meat was then crushed. The minced tilapia meat was washed 3 times using cold water at a ratio of 1:4. Draining was done between washing, after the last draining completed the meatwas then packaged and frozen-storage prior to use for the FPC preparation.Prior to lipid extraction, the frozen minced tilapia meat was thawed under room temperature and upon thawed the fish meat sample was then divided into two groups. One group was then pressed to remove part of free water while the other was not. Both groups were then subjected to lipid extraction using $90 \%$ ethanol with a ratio of solvent to fish meat was $2: 1$ and 4:1 with extraction time of 20,40 and 60 minutes with a regular stirring. The solvent was changed 3 times to prevent saturation. After a series of lipid extraction, the sample was dried in a forced-air convection oven at $65^{\circ} \mathrm{C}$ for 18 hours. The dried fish meat was grinded and sieved through a 100 mesh sieve to obtain the FPC flour.

\section{b. Physico-chemical analysis of the tilapia FPC}

\section{Chemical Parameters}

\section{Moisture content}

The moisture content analysis was carried following the Indonesian National Standard, SNI 2354.2:2015 [4] using a vacuum oven method.Firstly, an empty cup was placed in the oven and dried at $95^{\circ} \mathrm{C}-100^{\circ} \mathrm{C}$ for at least 2 hours. After that, the empty cup was transferred to a desiccator for 30 minutes until it reached room temperature and weighed (A). Then weigh as much as $\pm 2 \mathrm{~g}$ of the FPC flour in the cup (B).The cup containing the FPC sample was then dried in a vacuum oven at a temperature of $100^{\circ} \mathrm{C}$, with an air pressure of not more than $100 \mathrm{mmHg}$ for 5 hours. Then the cup was transferred using a clamp into a desiccator and allowed to stand for \pm 30 minutes and then weighed (C). The moisture content was as follows:

$$
\text { Moisture content }(\%)=\frac{B-C}{B-A} x 100
$$

A : weight of empty cup (g)

B : weight of cup + initial sample $(\mathrm{g})$

$\mathrm{C}$ : weight of cup + dry sample $(\mathrm{g})$

\section{Ash content}

The ash content was analysed according to the SNI 2354.1:2010 method [3]. The porcelain ashingcup to be used was pre-dried in the oven for 30 minutes at 100-105 ${ }^{\circ} \mathrm{C}$, then cooled in a desiccator and weighed (A). Approximately $2 \mathrm{~g}$ of the FPC flour were transferred into the driedashing cup and the weight was taken (B), then burned on a burner flame untilsmokeless and continued with ashing in a furnace at a temperature of 550-600 ${ }^{\circ} \mathrm{C}$ until complete ashing (occasionally the door of the furnace was opened slightly to allow oxygen to enter). The sample was cooled in a desiccator and weighed (C). The sample was repeatedly heated in the furnace until a constant weight was obtained. Ash content was calculated by the formula: 


$$
\text { Ash content }(\%)=\frac{C-A}{B-A} \times 100
$$

A : Weight of empty porcelain ashing cup (g)

B : Weight of porcelain ashing cup with sample before drying $(\mathrm{g})$

C : Weight of porcelain ashing cup with sample after drying $(\mathrm{g})$

\section{Protein content}

Analysis of protein content was carried out in accordance with SNI 01.3254.4:2006 [2] with a slight modification. A sample of an approximately $2 \mathrm{~g}$ of the FPC flour was weighed on a weighing paperand put in a digestion flask and thentwo catalyst tablets and a few boiling stones were added. Slowly add $15 \mathrm{ml}$ concentrated $\mathrm{H}_{2} \mathrm{SO}_{4}(95 \%-97 \%)$ and $3 \mathrm{ml} \mathrm{H}_{2} \mathrm{O}_{2}$ and let to stand for 10 minutes in the acid chamber. Destruction was then carried out at $410^{\circ} \mathrm{C}$ for \pm 2 hours or until the solution became clear, let to stand until it reached room temperature, then $50-75 \mathrm{ml}$ of distilled water was added. An erlenmeyer containing $25 \mathrm{ml}$ of a $4 \% \mathrm{H}_{3} \mathrm{BO}_{3}$ solution and a few drops of indicator was prepared to collect the distillate. The digestion flask was installed on a steam distillation apparatus and $50-75 \mathrm{ml}$ of sodium hydroxide solution were added. The distillation was until the volume of the distillate reached a minimum of $150 \mathrm{ml}$ The distillate was then titrated with a standardized $0.2 \mathrm{~N} \mathrm{HCl}$ until the color changes from green to neutral gray (natural gray). A blank was also prepared following the same procedure as for the sample. The protein content was calculated using a formula:

protein content $(\%)$

$=\frac{\left(V_{A}-V_{B}\right) \times H C l \times N H C l \times 14,007 \times 5,6 \times 100}{W \times 1000}$

$\mathrm{V}_{\mathrm{A}} \quad: \mathrm{ml} \mathrm{HCl}$ for sample titration

$\mathrm{V}_{\mathrm{B}} \quad: \mathrm{ml} \mathrm{HCl}$ for blank titration

$\mathrm{N}$ : Normality of standard $\mathrm{HCl}$ used.

14.007 : Atomic weight of nitrogen.

5,6 : Protein conversion factor for fish [11]

W : Sample weight $(\mathrm{g})$

Protein content is expressed in units of $\mathrm{g} / 100 \mathrm{~g}$ sample (\%).

\section{Fat content}

Fat content analysis was carried outby a Soxhlet method in accordance with SNI 2354-3:2017 [5].Carefully weigh $2 \mathrm{~g} \mathrm{(A)}$ of the sample in a $250 \mathrm{~mL}$ beaker. Add 20 $\mathrm{mL}$ of concentrated $\mathrm{p} . \mathrm{aHCl}$ and $30 \mathrm{~mL}$ of water and a few boiling stones. Then cover the beaker with a watch glass and simmer for 15 minutes. Rinse the watch glass with hot water. Then prepare a funnel and coarse filter paper. Strain hot and rinse with hot water until the $\mathrm{pH}$ is neutral or equal to the $\mathrm{pH}$ of the rinse water. Then dry the filter paper and its contents in an oven at a temperature of $100^{\circ} \mathrm{C}$ for 15 minutes. Take the weight of an empty round bottom flask (B g) and then insert the filter paper into the fat sleeve. Put $50 \mathrm{~mL}$ (or according to Soxhlet's volume) of diethyl ether into a round bottom flask. Then insert the fat sleeve into the Soxhlet extractor and install the Soxhlet circuit correctly. Extract the fat with an extraction cycle of about 5 minutes/cycle for 4 hours. Then vaporize the solvent in a round bottom flask to dryness. Put the round bottom flask containing fat into the oven at $105^{\circ} \mathrm{C}$ for \pm 2 hours to remove the remaining solvent and moisture. Cool the round bottom flask containing fat in a desiccator for 30 minutes. Weigh the round bottom flask containing fat $(\mathrm{Cg})$ to a constant weight. Calculate the fat content using a formula:

$$
\text { Fat content }(\%)=\frac{(C-B)}{A} \times 100
$$

A : sample weight (g)

B : weight of empty round bottom flask ( $\mathrm{g}$ )

$\mathrm{C}$ : weight of round bottom flask and extracted fat $(\mathrm{g})$.

\section{Physical Parameters}

\section{Whiteness}

The whiteness of the tilapia FPC flour was carried out according to [10]; [13].Measurement of sample whiteness was done digital colometer (T-135).The value of $\mathrm{L}$ (brightness), a (red-green mixed chromatic color) and b (blue-yellow mixed chromatic color) was measured by attaching the colometer sensor to the sample. The whiteness was calculated using the $\mathrm{L}$, a and $\mathrm{b}$ values obtained using a formula as follows [14]:

$$
W(\%)=100-\sqrt{(100-L)^{2}+a^{2}+b^{2}}
$$

$\mathrm{W}$ : degree of whiteness

$\mathrm{L}$ : brightness

a : red-green mix color (red if marked + and green marked -)

b : blue-yellow mix color (yellow if marked + and blue if marked -)

\section{Water absorption capacity[7]}

A sample of $1 \mathrm{~g}$ was put into a centrifuge tube and then added with $10 \mathrm{~mL}$ of distilled water, then stirred with a spatula and allowed to stand at room temperature for 30 minutes. After that it was centrifuged at 3,000 rpm for 30 
Table 1. The chemical characteristics of the niletilapia FPC

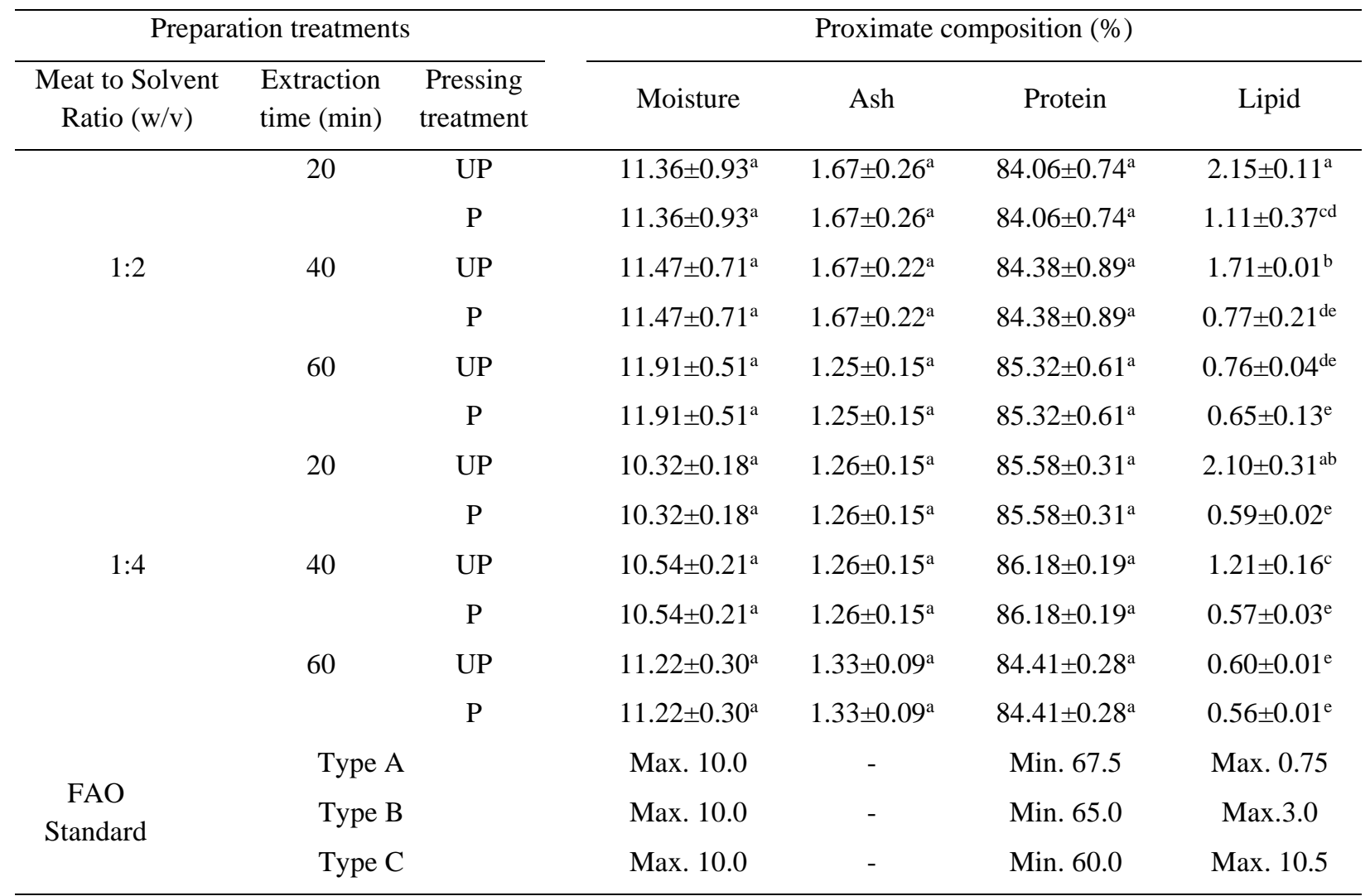

$\mathrm{UP}=$ unpressed; $\mathrm{P}=$ pressed

Valuesare means \pm standard deviations

Different letters showed significant differences between treatments at $\alpha=0.05$
minutes. The volume of unabsorbed water was then measured with a measuring cup.

$$
W A C=\frac{(\mathrm{W} 1+\mathrm{AW})-(\mathrm{W} 2+\mathrm{UAW}) \boldsymbol{m l}}{\text { weight of sample }(\mathrm{g})}
$$
WAC : water absorption capacity $(\mathrm{ml} / \mathrm{g})$
AW : absorbed water $(\mathrm{ml})$
UAW : unabsorbed water $(\mathrm{ml})$
W1 : initial weight $(\mathrm{g})$
W2 : final weight $(\mathrm{g})$

\section{Oil absorption capacity[7]}
A total of $1 \mathrm{~g}$ of sample and $10 \mathrm{~mL}$ of vegetable oil were put into a centrifuge tube, then stirred with a spatula for 1 minute. After being allowed to stand for 30 minutes, the tube was centrifuged at 3,000 rpm for 30 minutes. The volume of unabsorbed oil was measured with a measuring cup.

$$
O A C=\frac{(\mathrm{W} 1+\mathrm{AO})-(\mathrm{W} 2+\mathrm{UAO}) m l}{\text { weight of sample }(\mathrm{g})}
$$
OAC : oil absorption capacity $(\mathrm{ml} / \mathrm{g})$
AO : absorbed oil (ml)
UAO : unabsorbed oil $(\mathrm{ml})$
W1 : initial weight $(\mathrm{g})$
W2 : final weight $(\mathrm{g})$

\section{RESULTS AND DISCUSSIONS}
In general the chemica characteristics of food consist of protein, fat, water and ash contents which are also referred to as the proximate composition. In food analysis, chemical composition analysis is needed to find out the important components in foodstuffs. In addition, analysis of the physical characteristics of food ingredients is also very important, which consist of water absorption, oil absorption and whiteness, among others. The proximate composition of the tilapia FPC is presented in Table 1.


The main parameters for the quality standard of FPC according to FAO [6] namely protein content, fat content, aroma, and whiteness degree.The proximate composition in Table 1 showed that the nile tilapia FPC produced in this study contained $10.32-11.91 \%$ moisture, $1.25-$ $1.67 \%$ ash, $84.06-86.18 \%$ protein and $0.56-2.15 \%$ lipid. The ANOVA results indicated that the three treatment applied did not affect $(p>0.05)$ the moisture, ash and protein, but they did affect $(p<0.05)$ the lipid content of the FPC. The moisture content was slightly higher than the FAO standard, while the protein and lipid contents met the FAO standard for FPC of type A and B.However, FAO did not set any standard for ash content of the FPC. The higher moisture content than the FAO standard indicated that the drying duration of 18 hours at $65^{\circ} \mathrm{C}$ was not sufficient and, therefore either drying time should be prolonged to about 24 hours or the drying temperature be increase to $70^{\circ} \mathrm{C}$. Another possibility is that the out-flow of air from the oven might have been too slow, causing the air within the oven became relatively saturated by the water vapour, and hence, slowing the drying rate. Drying duration and temperature as well as air movement are the primary determinant of the moisture content of a substance.Longer drying duration and higher temperature as well as higher flow rate of the air remove more free water from a material being dried.A lower moisture contents of the FPC have been reported for rainbow runner(Elagatisbipinnulatus) $(8.26 \%)$ [16] and $6.34 \%$ [17], and for nile tilapia $(O$. niloticus)(9.34\%) [18].The differences in the moisture content might have been due to the differences in the mothods used to produce the FPCs.

In this study, higher ratio of solvent to meat tended to lower the ash content.Higher volume of solvent (ethanol) used enables more minerals contained in cytoplasm to be taken out of the cells, resulting lower ash contents. Ethanol is capable of breaking the cell wall and solubilizing the cytoplasm together with substances contained in it, including mineral dispersed in the cytoplasm. He ash content of the nile tilapia FPC of this study was generally comparable to that of the rainbow runner FPC (1.22\%) reported by [16].

The protein content of the FPC produced in this study was far above the minimum threshold of the FAO standard. The similarity of the protein content indicated that the treatments applied in this study did not compromise the nile tilapia FPC protein content. The protein in the FPC is primarily of the myofibril type because stroma protein is low (about $2.2 \%$ ) in fish muscle, and water soluble sarcoplasmic protein (about 2-3.5\% in teleost fish) is removed during washing. The protein content of the FPC of the present study was also much higher than those reported by [18] for rainbow runner (77.34\%) and by [18] for nile tilapia (61.13\%) FPCs.

Based on the lipid content, the FAO [6] classified the FPC into three types, namely type A (max.0.75\%), B (max.3\%) and $\mathrm{C}(\max .10 .5 \%)$. The results showed that the lipid content of the tilapia FPC in this study was 0.54$2.15 \%$, and therefore the FPC falls into type A and B categories. Higher solvent volume and longer extraction time as well as application of pressing produced lower lipid contents of the nile tilapia FPC. The results of ANOVA showed that the ratio of meat to solvent, extraction time and pressing treatment exerted significant $(p<0.05)$ effects on the lipid content of the nile tilapia FPC. A significant $(p<0.05)$ interaction between the three treatment factors was also existed. Tukey test also indicated the presence of significant $(\mathrm{p}<0.05)$ differences in the lipid contents of the FPC between treatments (Table 1). For the $1: 2(\mathrm{w} / \mathrm{v})$ ratio, only extraction time of 60 minutes with pressing produce the FPC of type A. The FPC of the 40 minutes extraction with pressing $(0.77 \%)$ potentially becomes the type A of FPC if the pressing force is greater. Similarly, the FPC of the 60 minutes extraction without pressing $(0.76 \%)$ may also become type $\mathrm{A}$ if the extraction time is longer. In contrast, for the 1:4 (w/v) ratio, only the FPC of the 20 and 40 minutes extraction time without pressing falls into type B category, whereas the rest falls into type A category of the FPC. This study also proves that pressing treatment helps reducing the lipid content of the FPC. If the purpose is to produce type A FPC, pressing should be a better choice of treatment in lowering the lipid of the FPC rather than increasing the volume of the organic solvent used. On the other hand, if the target product is type B FPC and considering that the moisture content between unpressed and pressed FPC was similar, there seems to be no need to apply pressing which will also reduce working load.

Physical characteristics such as degree of whiteness, water and oil absorption capacities are also important in determining the quality of the FPC. Table 2 showed that the degree of whiteness of the tilapia FPCs was similar ( $p>0.05$ ), meaning that all of the treatments applied caused no deleterious effects on the whiteness parameter. The whiteness degree of $85.9-88.2 \%$ is considered to be high, indicating a good performance of the processes used in the production of the nile tilapia FPC. Low degree of whiteness of an FPC is generally caused by several factors, such as the presence of heme protein, high fat content, too long drying at low temperature which permits fermentation process to take place, as well as too high drying temperature which facilitates browning reactions. According to [14], [15] and [18],extraction of meat 
removed fat, pigment, blood, and other components that affect odor and color.

Table 2. The physical characteristics of the niletilapia FPC.

\begin{tabular}{|c|c|c|c|c|c|}
\hline \multicolumn{3}{|c|}{ Preparation treatments } & \multicolumn{3}{|c|}{ Physical parameters } \\
\hline $\begin{array}{c}\text { FPC to } \\
\text { Solvent Ratio } \\
(\mathrm{w} / \mathrm{v})\end{array}$ & $\begin{array}{l}\text { Extraction } \\
\text { time (min) }\end{array}$ & $\begin{array}{l}\text { Pressing } \\
\text { treatment }\end{array}$ & Whiteness (\%) & WAC $(\mathrm{ml} / \mathrm{g})$ & $\mathrm{OAC}(\mathrm{ml} / \mathrm{g})$ \\
\hline \multirow{6}{*}{$1: 2$} & \multirow[t]{2}{*}{20} & UP & $86.7 \pm 1.41^{\mathrm{a}}$ & $2.14 \pm 0.01^{\mathrm{a}}$ & $2.39 \pm 0.06^{\mathrm{a}}$ \\
\hline & & $\mathrm{P}$ & $86.2 \pm 0.40^{\mathrm{a}}$ & $2.14 \pm 0,01^{\mathrm{a}}$ & $2.39 \pm 0.06^{\mathrm{a}}$ \\
\hline & \multirow[t]{2}{*}{40} & UP & $86.3 \pm 0.72^{\mathrm{a}}$ & $2.21 \pm 0.03^{\mathrm{a}}$ & $2.51 \pm 0.11^{\mathrm{a}}$ \\
\hline & & $\mathrm{P}$ & $86.0 \pm 1.71^{\mathrm{a}}$ & $2.21 \pm 0.03^{\mathrm{a}}$ & $2.51 \pm 0.11^{\mathrm{a}}$ \\
\hline & \multirow[t]{2}{*}{60} & UP & $86.5 \pm 1.51^{\mathrm{a}}$ & $2.43 \pm 0.03^{\mathrm{a}}$ & $2.37 \pm 0.10^{\mathrm{a}}$ \\
\hline & & $\mathrm{P}$ & $85.9 \pm 1.05^{\mathrm{a}}$ & $2.43 \pm 0.03^{\mathrm{a}}$ & $2.37 \pm 0.10^{\mathrm{a}}$ \\
\hline \multirow{6}{*}{$1: 4$} & \multirow[t]{2}{*}{20} & UP & $87.3 \pm 0.38^{\mathrm{a}}$ & $2.21 \pm 0.02^{\mathrm{a}}$ & $2.51 \pm 0.16^{\mathrm{a}}$ \\
\hline & & $\mathrm{P}$ & $86.6 \pm 0.10^{\mathrm{a}}$ & $2.21 \pm 0.02^{\mathrm{a}}$ & $2.51 \pm 0.16^{\mathrm{a}}$ \\
\hline & \multirow[t]{2}{*}{40} & UP & $85.9 \pm 0.53^{\mathrm{a}}$ & $2.54 \pm 0.05^{\mathrm{a}}$ & $2.41 \pm 0.05^{\mathrm{a}}$ \\
\hline & & $\mathrm{P}$ & $86.8 \pm 0.17^{\mathrm{a}}$ & $2,54 \pm 0.05^{\mathrm{a}}$ & $2.41 \pm 0.05^{\mathrm{a}}$ \\
\hline & \multirow[t]{2}{*}{60} & UP & $88.2 \pm 1.63^{\mathrm{a}}$ & $2.20 \pm 0.04^{\mathrm{a}}$ & $2.44 \pm 0.06^{\mathrm{a}}$ \\
\hline & & $\mathrm{P}$ & $86.4 \pm 0.31^{\mathrm{a}}$ & $2.20 \pm 0.04^{\mathrm{a}}$ & $2.44 \pm 0.06^{\mathrm{a}}$ \\
\hline \multirow{3}{*}{ FAO Standard } & & Type A Max & - & - & - \\
\hline & & Type B Max & - & - & - \\
\hline & & Type C Max & - & - & - \\
\hline
\end{tabular}

$\mathrm{UP}=$ unpressed; $\mathrm{P}=$ pressed

Valuesare means \pm standard deviations.

Different letters showed significant differences between treatments at $\alpha=0.05$

Water and oil absorptionsare the determinant factors of shelf life of the FPC. Water absorption capacity (WAC) is the ability to hold water from outside and inside in food ingredients, whereas oil absorption capacity is the ability a material to interact with oil. The results showed that the WAC values of the tilapia FPCswere distributed in a very narrow range between 2.14 and $2.54 \mathrm{ml} / \mathrm{g}$, and werestatistically similar ( $p>0.05)$ for the whole treatments given.Similarly, the oil absorption capacity (OAC) was also unaffected by the treatments applied during the production of the tilapia FPC. Like the WAC, the values of OAC were also distributed in a very narrow range between 2.37 and $2.51 \mathrm{ml} / \mathrm{g}$, and were statistically similar $(\mathrm{p}>0.05)$ for the whole treatments given. Therefore, the treatments used in this study did not affect $(\mathrm{p}>0.05)$ the WAC and OAC of the tilapia FPC. According to [15], water absorption of FPC shows interaction of protein with water, while [19] stated that oil absorption showsinteraction of protein and oil. The WAC of the FPC flour in this study was lower than that of carbohydrate flours which is generally 3 times higher than their weight. Therefore, protein concentrate flour has lower capacity to absorb water as compare to carbohydrate flour. So far, there has not been any standard set for the WAC and OAC of the FPC.

\section{CONCLUSIONS}

The present study demonstrated that the ratio of solvent to fish meat, extraction time and pressing treatment did not affect the physic-chemical parameters of the nile tilapia FPC, except for the lipid content. Treatments and method used in the preparation of the nile tilapia FPC were successful in producing good quality of type A and B FPC. Nonetheless, some improvements are still required in order to produce an even better quality of the FPC, especially related to the method of reducing the moisture to meet the standard outlined by the FAO. The FPC from this study also demonstrated that nile tilapia is a good raw material for the FPC production. 


\section{REFERENCES}

[1] AOAC. 1995.Official Methods of Analysis.The Association of Official Analytical Chemists. Washington DC.

[2] SNI. (2006). Cara Uji Kimia-Bagian 4: Penentuan Kadar Protein DenganMetode Total Nitrogen Pada Produk Perikanan. SNI 01-2354.4-2006.Standar Nasional Indonesia. Badan Standarisasi Nasional. Jakarta.

[3] SNI. (2010). Cara Uji Kimia-Bagian 1: Penentuan Kadar Abu dan Abu Tak Larutdalam Asampada Produk Perikanan. SNI 2354.1:2010. Standar Nasional Indonesia. Jakarta..

[4] SNI. (2015).Penentuan kadar air. SNI 2354.2:2015. Standar Nasional Indonesia. Badan Satandarisasi Nasional. Jakarta.

[5] SNI. (2017). Cara Uji Kimia-Bagian3: Penentuan Kadar Lemak Total pada Produk Perikanan. SNI 2354.3:2017. Standar Nasioanl Indonesia.Badan Standarisasi Nasional.Jakarta.

[6] FAO.(1991). Guedline on formulated suplementary foods for older infants and young children. Rome (IT): Food and agriculture organization.

[7] Beuchat, L.R. (1977). Functional and electrophoretic characteristics of succinylated peanutflour protein. J.Agric Food Chem. 25 (6): 258-261.

[8] Faridah, D.N, Kusumaningrum, H.D, Wulandari, N, Indrasti, D. (2006). Modul Praktikum Analisisi Pangan. Bogor :DepartemenIlmu Dan Teknologi Pangan. Fakultas Teknologi Pertanian. Institut Pertanian Bogor.

[9] Ibrahim, M.S. (2009). Evalution of production and quality of saltbiscuits supplemented with fish protein consentrate. World J. Dairy Food Sciences. 4 (1) : 28-31.

[10] Kuswadi, B., Maryska, C., Jayus, Abdullah, A. (2013). Heng LY. Real time on package freshness indicator for guavas packaging. J. Food Meas Charact. 7 (1) : 29-39.

[11] Mariotti, F., Tome, D., Mirand, P. (2019). Converting notrogen into protein - beyound 6,25 and jones' factors. Critical Reviews in Food Scince and Nutrition, Taylor \& Francis, 2008, 48 (2), pp. 177-184.

[12] Mawarni, R.,T.dan Widjanarko, S.,B.(2015). Penggilingan metode ball mill dengan pemurnian kimia terhadap penurunan oksalat tepung porang. J. Pangan dan Agroindustri. Vo. 3. No 2. p. 571-581.

[13] Nuhamunada, M., Ramadhani, N. (2018). Lipid content from monoculture of micro algae chlorella zofingiensis donz and mied culture of glagha biodiesel production. Asian. J. Microbiol biotech. Env Sc. 18 (1) : 95-100..

[14] Rawdkuen, S., Smart, S.U., Khamsorn, S., Chaijan, M., Benjakul S. (2009). Biochemical and gelling properties of tilapia surimi and proteinrecovered using an acid-alkaline process. Food Chemistry. 112: 112-119. -52.

[15] Rieuwpassa, F.J, Santoso, J, and Trilaksani, W. (2013). Karakterisasisifatfungsionalkosentrat protein telurikancakalang (Katsuwonuspelamis). J. Ilmudan Teknologi KelautanTropis. 5(2) : 299-309.

[16] Riewpessa, F.J, dan Cahyono, E. (2019). Kararkteristikfisiko-kimiakonsentrat protein ikansunglir (Elagatisbipinnulatus). J. MIPA Unsart Online 8 (3). 164167.

[17] Riewpessa, F.J, Karimela, E.J, dan Cindy, D.L. (2018). Kararkteristiksifatfungsionalkonsentrat protein ikansunglir
(Elagatisbipinnulatus).J. TeknologiPerikanandanKelautan Vol. 9. No 2. 177-183.

[18] Riewpessa, F.J, Karimela, E.J, dan Karaeng, M.C. (2020). Analisisfisikokimikonsentrat protein ikannila (Oreochromisniloticus) yang diekstrakmeng gunakanpelarutetanol. J. Teknologi Perikanandan Kelautan Vol. 11. No $1: 45-52$.

[19] Santoso, J. Hendra, E., Siregar, T.M. (2008). Pengaruh lama dan pengulangan ekstraksi terhadap karakteristik fisikokimia konsentrat protein ikan nila hitam (Oreochromis niloticus). J. Ilmu dan Teknologi Pangan. 6 (2) 67-85.

[20] Wiharja, S.Y., Santoso, J., Yakin, L.A. (2013). Utilization of yellowfin tuna and red snapper roer protein concentrate as emulisfier in mayonnaise. journal of Food Science and Engeneering 3 (2013) 678-687. 